\title{
FROM THE DESK OF EDITOR in CHIEF
}

(J Bangladesh Coll Phys Surg 2016; 34: 243)

Dear Fellow,

AssalamuAlaikum.

I am happy to furnish this issue of our beloved journal with some splendid articles and hope it will serve well to satisfy you. For instance, "Incidence of Gallbladder Carcinoma in Thick Walled Gallbladder in Comparison with that of Normal Thickness - A Study of 300 Cases"by MM Hasana, SZ Lailab, MH Mamun is a unique study that shows that incidence of malignancy was higher $(84.62 \%)$ in patients having thick walled Gall Bladder and highlighted the doctrine that all specimen should undergo histopathology after cholecystectomy. "Hepatitis B Virus, Hepatitis C Virus Markers and Serum Alanine Amino-Transferase Levels (ALT), in a Young
Adult Population of Sylhet District" is another great initiative by our fellows to increase the awareness and augment preventive measures against viral hepatitis related morbidity. I hope that our fellows will take lead in making larger scale researches successful in our country in the coming year and our journal will be enriched by many more brilliant publications.

Thank you.

\author{
Prof. Khan Abul Kalam Azad \\ Editor-in-Chief \\ Journal of BCPS
}

